\title{
Texture Softening of Beef and Chicken by Enzyme Injection Process
}

\author{
Sung-Hwan Eom ${ }^{1}$, Sang-Hoon Lee ${ }^{1,2}$, Yong-Gi Chun ${ }^{1}$, Bum-Keun Kim¹, and Dong-June Park ${ }^{1 *}$ \\ ${ }^{1}$ Korea Food Research Institute, Sungnam, 463-746, Korea \\ ${ }^{2}$ University of Science and Technology, Daejeon 305-350, Korea
}

\begin{abstract}
This research focuses on a new softening technology for use with chicken breast and eye of round beef in order to assist elderly individuals who have difficulty with eating due to changes in their ability to chew (masticatory function) or swallow. We investigated the hardness of chicken breast and eye of round beef through use of a texture analyzer after injection of a commercial enzyme. Among 7 commercial enzymes, bromelain and collupulin exhibited a marked softening effect on the tested chicken breast and eye of round beef given a $1.00 \%$ enzyme concentration. The hardness of bromelain-treated chicken breast reached $1.4 \times 10^{4} \mathrm{~N} / \mathrm{m}^{2}$, of collupulin-treated chicken breast reached $3.0 \times 10^{4} \mathrm{~N} / \mathrm{m}^{2}$, and of bromelain-treated eye of round beef reached $3.2 \times 10^{4} \mathrm{~N} / \mathrm{m}^{2}$, respectively, while their original shapes did not change. To find the level of tissue degradation with specific enzyme concentrations, enzyme injections at $0.1 \%, 0.25 \%$, $0.50 \%$, and $1.00 \%$ concentration of bromelain and papain were also evaluated. The results of this research could be useful for softening chicken breast and eye of round beef and will contribute to the development of foods that can be more easily eaten as part of a balanced diet for elderly adults.
\end{abstract}

Keywords: bromelain, chicken breast, collupulin, enzyme injection, eye of round beef, hardness

Received April 6, 2015; Revised June 10, 2015; Accepted June 11, 2015

\section{Introduction}

The rapid movement towards an aging society is unprecedented among the countries in the Organization for Economic Cooperation and Development (OECD) (Kim, 2000). According to the Korea National Statistical Office, 15.7\% of the Korean population was 65 years and older (elderly ratio) in 2010. The ratio is expected to continue to rise.

The aging process is associated with gradual and progressive loss of muscle mass along with lowered strength and physical endurance (Deutz et al., 2014). In elderly people, age-related deterioration of the masticatory or swallowing functions is common and affects their perceptions and choices of food and their ability to eat. Swallowing disorders are particularly common and may cause dehydration, weight loss, aspiration pneumonia, and airway obstruction (Palmer et al., 2000; Rothenberg et al., 2007; van der Bilt, 2002). Accordingly, the need exists for soft foods as "care food" that can be used in nursing homes and assisted living facilities as well as during reha-

\footnotetext{
*Corresponding author: Dong-June Park, Division of Industrial Promotion Research, Korea Food Research Institute, Seongnam 463-746, Korea. Tel: +82-31-780-9132, Fax: +82-31-709-9876, E-mail: djpark@kfri.re.kr
}

bilitation in a hospital setting. However, boiled, minced, and paste foods are served at hospitals and nursing homes in spite of the fact that they are less palatable in appearance and flavor than are normally cooked foods.

Among various food energy sources, protein is an important macronutrient used by the body for building, repairing, and maintaining muscle function. Consuming an adequate amount of protein can help adults sustain muscle strength and function (Deutz et al., 2014; Hoffman and Falvo, 2004). Although dietary data for the elderly are limited, it has been reported that the optimal protein intake for older adults is greater than their current recommended dietary allowance (RDA) and that increasing protein intake to approximately $1.5 \mathrm{~g}$ protein $/ \mathrm{kg} /$ day may be ideal (Wolfe et al., 2008). Concerns about the potential detrimental effects of increased protein intake on bone health, renal function, neurological function, and cardiovascular function are generally unfounded. Among the different types of protein-containing foods, chicken breast and eye of round beef are considered to provide highquality protein and to be good sources of minerals such as iron, niacin, selenium, phosphorus, choline, iron magnesium, vitamin $\mathrm{B}_{6}$, and vitamin $\mathrm{B}_{12}$ (Keen and ZidenbergCherr, 1994; Williams, 2007). In addition, both chicken breast and eye of round beef contain more protein and less

(9)This is an open access article distributed under the terms of the Creative Commons Attribution Non-Commercial License (http://creativecommons.org/licences/ by-nc/4.0) which permits unrestricted non-commercial use, distribution, and reproduction in any medium, provided the original work is properly cited. 
fat in comparison to many other potential protein sources.

This research was undertaken to verify and evaluate the effects of a protease enzyme injection on chicken breast and eye of round beef on tenderness. The goal of this research is to help elderly Koreans significantly improve their protein intake and their general health with palatable foods that can be eaten without excessive difficulty.

\section{Material and Methods}

\section{Eye of round beef}

For this study, the round was divided into cuts including the eye of round, bottom round, and top round. Eye of round was obtained from Dongah Food Co., LTD. (Korea), which imported the beef from Swift ${ }^{\circledR}$ Beef Company (Greeley, USA). This boneless beef consists only of the semitendinosus muscle. The meat was cut into four equal parts and stored at $-20^{\circ} \mathrm{C}$ in the freezer. The frozen eye of round was thawed slowly in a refrigerator at $4^{\circ} \mathrm{C}$ overnight, sliced into $2 \mathrm{~cm}$-thick chops perpendicular to the fiber direction, and cut into $8 \mathrm{~cm} \times 8 \mathrm{~cm}$ pieces.

\section{Chicken breast meat}

Frozen boneless chicken breasts were purchased from a commercial chicken company (Harim Co., Ltd., Korea) and kept at $20^{\circ} \mathrm{C}$ in the freezer. Frozen chicken breast was thawed slowly in a refrigerator at $4{ }^{\circ} \mathrm{C}$ overnight and sliced into $2 \mathrm{~cm}$-thick chops perpendicular with both end pieces except for smaller pieces/quantities.

\section{Enzyme solution for softening samples}

The following softening enzymes were used: Alcalase 2.4L FG (Alc; Novozymes, Denmark), Neutrase 0.8L (Neu; Novozymes), Flavourzyme 500MG (Fla; Novozymes), Protamex (Pro; Novozymes), Collupulin MG (Coll; DSM Food Specialties, Netherlands), Alphalase NP (Alp; DuPont Danisco, USA), and Bromelain 1200 GDU (Bro; Great Food [Biochem] Co. Ltd., Thailand). Conditions of the enzyme solutions were as follows: $1.0 \%(\mathrm{v} / \mathrm{v})$ Alc, $1.0 \%$ (v/v) Alp, 1.0\% (w/v) Bro, 1.0\% (w/v) Fla, 1.0\% (w/v) Coll, 1.0\% (v/v) Neu, and 1.0\% (v/v) Pro. All enzyme solutions were made using $0.1 \mathrm{M}$ phosphate buffered saline (PBS) buffer (Biosesang Inc., Korea) at pH 7.0.

\section{Determination of protease activity}

The protease activity of all the tested enzymes was determined as the substrate following the method of CuppEnyard (2008) with slight modification. One unit of protease (Alc, Alp, Bro, Coll, Fla, Neu, and Pro) was defined as the amount of enzyme required to produce $1 \mathrm{mg}$ of tyrosine from casein in $10 \mathrm{~min}$. For each enzyme, $1 \mathrm{~mL}$ (10 mg of enzyme powder or $10 \mu \mathrm{L}$ of enzyme solution in $50 \mathrm{~mL}$ of potassium phosphate buffer, $\mathrm{pH}$ 7.5) was added to $5 \mathrm{~mL}$ of $0.65 \%(\mathrm{w} / \mathrm{v})$ casein (Sigma Chemical Co., USA) substrate solution; enzyme was not added to one of the substrate solutions (leaving a "blank" unmodified substrate). After enzyme incubation for $10 \mathrm{~min}$ at $37^{\circ} \mathrm{C}$, the reaction was stopped by the addition of $5 \mathrm{~mL}$ of 0.11 $\mathrm{M}$ trichloroacetic acid (Sigma Chemical Co.) and was kept at $37^{\circ} \mathrm{C}$ for $30 \mathrm{~min}$. Then, the precipitate was finally filtered off using a $0.45 \mu \mathrm{m}$ PVDF syringe filter (Whatman, USA) and the amount of soluble digested peptides in the filtrate was estimated. $2 \mathrm{~mL}$ of filtrate was taken and added to $5 \mathrm{~mL}$ of $0.5 \mathrm{M}$ sodium carbonate (Junsei Co., Japan) and $1 \mathrm{~mL}$ of $0.5 \mathrm{M}$ Folin and Ciocalteu's reagent (Sigma Chemical Co.) since the released tyrosine developed a blue coloration (Bartkiene et al., 2013). The reaction mixture was incubated at $37^{\circ} \mathrm{C}$ for $30 \mathrm{~min}$ and the absorbance of the colored solution at $660 \mathrm{~nm}$ was measured using a Spectra Max M3 spectrophotometer (Molecular Devices, USA). Tyrosine (Sigma Chemical Co.) was used as the standard and the enzyme activity was calculated in $\mathrm{U} / \mathrm{mL}$ or $\mathrm{U} / \mathrm{mg}$.

\section{Injection and enzyme reaction}

To infuse the enzyme into the intercellular spaces, a thawed sample was injected with the $10 \%$ enzyme solution (based on the weight of the meat) perpendicular to the direction of the muscle fiber at approximately $1.0-\mathrm{cm}$ intervals using a syringe. The ratio of enzyme volume to the pieces of eye of round and chicken breast was 1:10 (based on the weight of meat) (Liu et al., 2011). Injected and non-injected samples were stored for $24 \mathrm{~h}$ at $4{ }^{\circ} \mathrm{C}$ for equilibrium to inactivate enzymes (Harris et al., 2001). The samples were exposed to steam treatment for $10 \mathrm{~min}$ utes in order to inactivate the enzyme (Nakatsu et al., 2012). After steaming, the samples were immediately cooled in a water bath using ice. To select the optimal enzyme, further injections were performed with enzyme concentrations of $0.10 \%, 0.25 \%, 0.50 \%$, and $1.00 \%$ prepared in a PBS buffer.

\section{Mechanical properties}

The texture of protein-based foods was measured with a TA.HD Plus Texture Analyser (Stable Micro Systems Ltd., U.K.) equipped with a 50-kg load cell. All textural analyses were carried out using Texture Exponent software version 6.1.5.0. (Stable Micro Systems Ltd.) by a 
slight modification of a previously described method (Sakamoto et al., 2006). The preparation procedure (duration of cooking; time period between cooking and testing) was the same for all tested samples. The hardness of the steamed sample was measured for each enzyme using an 10-mm cylinder probe with the following instrument settings: measured force in compression, pre-test speed: 1.0 $\mathrm{mm} / \mathrm{s}$; test speed: $2.0 \mathrm{~mm} / \mathrm{s}$; post-test speed: $10.0 \mathrm{~mm} / \mathrm{s}$; strain: $70 \%$; trigger force: $10 \mathrm{~g}$. The maximum force correlates to the hardness of the sample. The tests were performed on 10 replicates per sample. The sample was positioned centrally under the probe during testing.

\section{Statistical analysis}

All experiments were repeated in triplicate; statistical significance was confirmed using Duncan's Multiple Range Test. Statistical analysis was performed using IBM SPSS Statistics version 20.0 for Windows (IBM/SPSS Inc., USA).

\section{Results and Discussion}

\section{Selection of the softening enzymes for use in chicken breast}

Seven commercial proteases selected for their softening ability were examined to determine their softening effect in the chicken breast. These seven enzymes have been classified as 'Generally Recognized as Safe' and come from varying plant, bacterial, and fungal sources. The enzymes are also used to treat cuts of meat and enhance tenderness. It has been shown that different enzymes react differently to the myofibrillar and connective tissue portions of the meat (Calkins and Sullivan, 2007). The characteristics and test conditions of each enzyme are described in Table 1.

According to Goto et al. (2008), we also tried to apply a vacuum pressure impregnation technique for the chic- ken breast. With this technique, the chicken breast was immersed in a $1 \%$ protease solution at room temperature, and subjected to a decompression treatment for $20 \mathrm{~min}$ under a reduced pressure of 20,000 $\mathrm{Pa}$ using the volume deairation equipment (Datsukikun VP-2; Thermal Chemical Industrial Co., Ltd., Japan). However, the enzyme was decreased in the central region of the tissues using this vacuum pressure technique. Thus, we sought the enzyme injection that would have a sufficient amount of the enzyme present the central region of chicken breast (data not shown).

To select the enzymes that would be most appropriate for softening chicken breast, the effect of different commercial enzymes on the hardness of chicken breast was compared to control conditions using by TA.HD Plus Texture Analyser. Fig. 1 shows the different hardness values for chicken breast treated with different enzymes when compared to the control without the enzyme addition. The hardness value for the chicken breast before the treatment was $3.4 \times 10^{5} \mathrm{~N} / \mathrm{m}^{2}$. Of the 7 enzymes tested, 6 enzymes (Alc, Alp, Bro, Coll, Neu, and Pro) softened the chicken breast to $1.7 \times 10^{5} \mathrm{~N} / \mathrm{m}^{2}$ or less; Fla was the exception. Bro and Coll were shown to have a particularly pronounced softening effect on the chicken breast. Bro and Coll softened the chicken breast to $1.5 \times 10^{4} \mathrm{~N} / \mathrm{m}^{2}$ and $3.0 \times 10^{4} \mathrm{~N} / \mathrm{m}^{2}$, respectively. Although Bro and Coll designated by the same letter are not statistically different at the 0.05 level, Brom was a little superior to Coll in softening chicken breast, thereby demonstrating the potential effect of selective enzymes on softness. Therefore, Brom and Pap were used for treating the chicken breast in a dose-dependent manner.

\section{Influence of enzyme concentration on the hardness of the chicken breast}

To investigate the optimal enzyme to soften the chicken breast, the influence of the concentrations of the two

Table 1. Optimal softening conditions of various enzymes

\begin{tabular}{|c|c|c|c|c|c|c|}
\hline \multirow{2}{*}{ Enzyme } & \multicolumn{2}{|c|}{ Optimum conditions } & \multirow{2}{*}{ Buffer used } & \multirow{2}{*}{ Enzyme composition } & \multirow{2}{*}{ Protease activity } & \multirow{2}{*}{ Company } \\
\hline & $\mathrm{pH}$ & Temp. & & & & \\
\hline Alcalase 2.4L FG & 7.0 & $50^{\circ} \mathrm{C}$ & $0.1 \mathrm{M} \mathrm{PB}^{\mathrm{a}}$ & endoprotease & $235.04 \pm 6.85$ units $/ \mathrm{mL}$ & Novozymes \\
\hline Alphalase NP & $6.5-6.8$ & $60^{\circ} \mathrm{C}$ & $0.1 \mathrm{M} \mathrm{PB}$ & protease & $239.26 \pm 6.72$ units $/ \mathrm{mL}$ & Danisco-DuPont \\
\hline Bromelain $1200 \mathrm{GDU}$ & 7.0 & $50^{\circ} \mathrm{C}$ & $0.1 \mathrm{M} \mathrm{PB}$ & proteolytic enzyme & $183.58 \pm 4.02$ units $/ \mathrm{mg}$ & $\begin{array}{c}\text { Great Food (Biochem) } \\
\text { Co. Ltd. }\end{array}$ \\
\hline Collupulin MG & 7.0 & $65^{\circ} \mathrm{C}$ & $0.1 \mathrm{M} \mathrm{PB}$ & cysteine protease & $179.07 \pm 8.56$ units $/ \mathrm{mg}$ & DSM food specialties \\
\hline Flavourzyme 500MG & 7.0 & $50^{\circ} \mathrm{C}$ & $0.1 \mathrm{M} \mathrm{PB}$ & aminopeptidase, exopeptidase & $225.42 \pm 7.41$ units $/ \mathrm{mg}$ & Novozymes \\
\hline Neutrase $0.8 \mathrm{~L}$ & 7.0 & $50^{\circ} \mathrm{C}$ & $0.1 \mathrm{M} \mathrm{PB}$ & endoprotease & $225.32 \pm 7.15$ units $/ \mathrm{mL}$ & Novozymes \\
\hline Protamex & 7.0 & $50^{\circ} \mathrm{C}$ & $0.1 \mathrm{M} \mathrm{PB}$ & protease serine, endoprotease & $233.65 \pm 6.21$ units $/ \mathrm{mg}$ & Novozymes \\
\hline
\end{tabular}

${ }^{\text {a } P B, ~ p h o s p h a t e ~ b u f f e r . ~}$ 


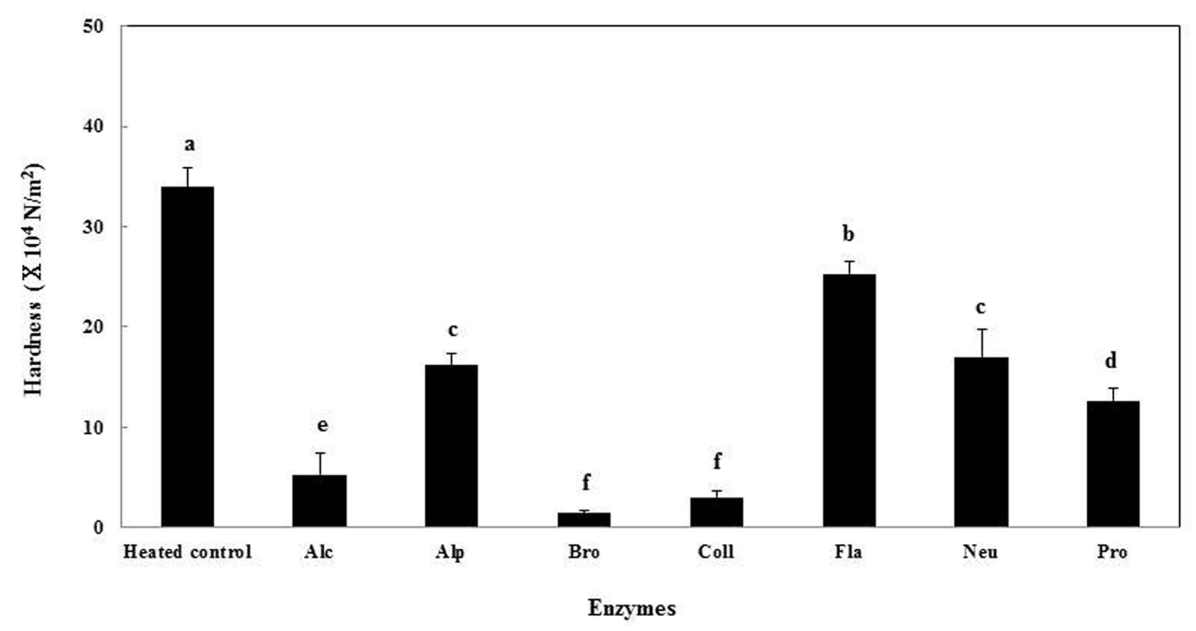

Fig. 1. Hardness of chicken breast processed using the enzyme injection method. Reactions were carried out at $4^{\circ} \mathrm{C}$ for $24 \mathrm{~h}$. Different letters indicate statistically significant difference $(p<0.05)$. Alc, alcalase 2.4L FG; Alp, alphalase NP; Bro, bromelain 1200 GDU; Coll, collupulin MG; Fla, flavourzyme 500MG; Neu, neutrase 0.8L; Pro, protamax.

selected enzymes on the hardness were investigated. The results are shown in Fig. 2. Chicken breast treated with injection of Brom gave a hardness of $3.8 \times 10^{4} \mathrm{~N} / \mathrm{m}^{2}$ at an enzyme concentration of $0.25 \%, 2.1 \times 10^{4} \mathrm{~N} / \mathrm{m}^{2}$ at $0.50 \%$, and $1.5 \times 10^{4} \mathrm{~N} / \mathrm{m}^{2}$ at $1.00 \%$, showing a great degree of softening (Fig. 2(a)). The sample shape at concentrations of $0.25 \%, 0.50 \%$, and $1.00 \%$ was only retained in a state in which the slightest stress caused the disintegration and coming apart of the softened chicken breast. In contrast, these samples were softened a little at concentrations of $0.100 \%$.

With the Coll enzyme, the hardness of the chicken breast was measured at $2.6 \times 10^{4} \mathrm{~N} / \mathrm{m}^{2}$ at an enzyme concentration of $1.0 \%$ and $3.8 \times 10^{4} \mathrm{~N} / \mathrm{m}^{2}$ at $0.50 \%$, showing a great degree of softening. As with Brom, the slightest stress led to the disintegration of the sample (Fig 2(b)). In contrast, the samples were softened a little at decreased concentrations of $0.25 \%$ and less at decreased concentrations of $0.10 \%$. At $0.50 \%$ and $1.00 \%$ concentration, the chicken breast was softened but also completely retained its shape.

The Japan Care Food Conference has established the Universal Design Foods (UDF) concept, in which food is classified into 4 categories based on hardness and viscosity (Japan Care Food Conference, 2011). The UDF concept has provided consumers with the standard at the time of choosing goods (Evaluation of Food Texture; Goto et al., 2008). A hardness of category 1 is below $5 \times 10^{5} \mathrm{~N} / \mathrm{m}^{2}$ and reflects softened meat that is easy to chew. Category

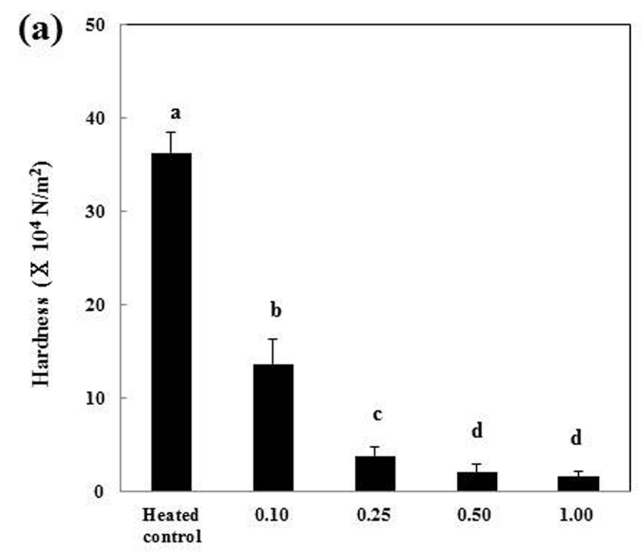

(b)

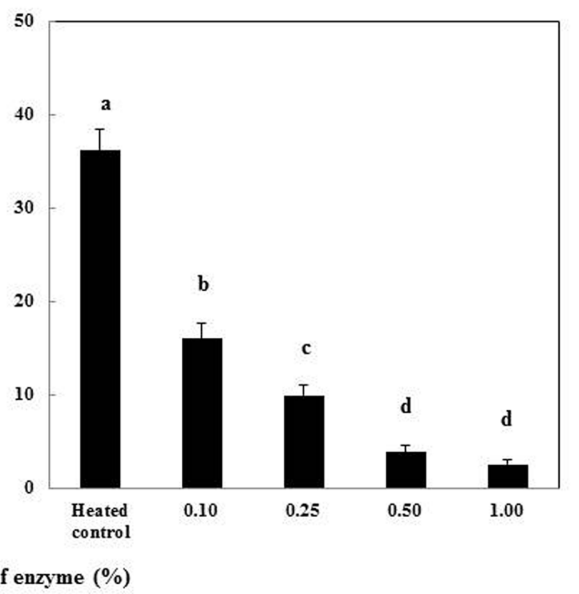

Fig. 2. Effect of enzyme concentrations on hardness of chicken breast processed using the enzyme injection method. Enzyme reactions were carried out at $4^{\circ} \mathrm{C}$ for $24 \mathrm{~h}$. Different letters indicate statistically significant difference $(p<0.05)$. (a) bromelain, (b) collupulin. 
2 meat is $5 \times 10^{4} \mathrm{~N} / \mathrm{m}^{2}$ and can be broken up using the gums; category 3 is $1.0 \times 10^{4} \mathrm{~N} / \mathrm{m}^{2}$ (the case of the sol) and can be broken up by the tongue, and category 4 is $3.0 \times 10^{3}$ $\mathrm{N} / \mathrm{m}^{2}$ (the case of the sol) and does not need chewing.

Softened food can be produced so that its hardness can be adjusted using enzyme treatments (Chizu et al., 2013). The present research shows that chicken breast treated with injections of Brom or Coll can be used for the diet of elderly individuals who have challenges with mastication and swallowing; when prepared as described, chicken breast falls under the category of UDF 2. Chicken breast treated with Bro at $0.25 \%, 0.50 \%$, and $1.00 \%$ can be broken up using the gums; also recognized as UDF 2 is chicken breast treated with Coll at concentrations of $0.50 \%$ and $1.00 \%$.

\section{Selection of the softening enzymes in the eye of round beef}

Since eye of round beef is usually used for beef jerky, or marinated grilled beef in Korea, it is one of the familiar dishes to elderly Koreans (Kwon et al., 2013). In this study, we investigated the effect a protease enzyme can have when used to soften eye of round beef. However, protease enzymes do not penetrate eye of the round; the method of enzyme injection was evaluated as being important with respect to ensuring uniform distribution in the meat. Since only limited knowledge has been obtained regarding the application of enzymes to soften eye of round beef, we have tried to examine the effect of seven exogenous enzymes (Table 1). According to Calkins and Sullivan (2007), these enzymes have also been added to meat to enhance tenderness and react differently to the myofibrillar and connective tissue portions of the meat.

Likewise, we evaluated the softening effects of commercial enzymes on chicken breast to select the most appropriate enzymes in comparison to the predefined control conditions. Fig. 3 shows the different hardness values for eye of round beef treated with different enzymes when compared to the control group (which did not have added enzymes). The hardness values for eye of round beef before treatment were $6.7 \times 10^{5} \mathrm{~N} / \mathrm{m}^{2}$. Among seven enzymes tested, five enzymes (Alc, Bro, Coll, Neu, and Pro) softened eye of round beef to $2.8 \times 10^{5} \mathrm{~N} / \mathrm{m}^{2}$ or less (Alp and Fla did not). Bro softened eye of round beef to $3.2 \times 10^{4} \mathrm{~N} /$ $\mathrm{m}^{2}$ in five enzymes, thereby demonstrating the efficacy of selective enzymes in softening eye of round beef. Takei $e t$ al. (2015) reported that the enzyme solution containing $0.007 \% \mathrm{w} / \mathrm{w}$ papain and $0.001 \% \mathrm{w} / \mathrm{w}$ bromelain was injected into raw Australian beef top round cuts through 16 needles (four needles $/ \mathrm{cm}^{2}$ ) until the weight of the meat increased by $50 \%$. Although the enzyme concentrations are about 4 times higher than those in this study, the firmness value of top round was calculated at $3.3 \times 10^{4} \mathrm{~N} / \mathrm{m}^{2}$. Therefore, further investigations are needed to elucidate the optimal condition among multiple potential enzyme concentrations to treat eye of round beef.

\section{Influence of enzyme concentration on the hardness of eye of round beef}

To find the optimal enzyme concentration to soften eye of round beef, Brom was used in a dose-dependent manner. Fig. 4 shows the influence of two enzymes and their concentration on the hardness of the eye of round beef. The beef treated with an injection of Brom gave a hard-

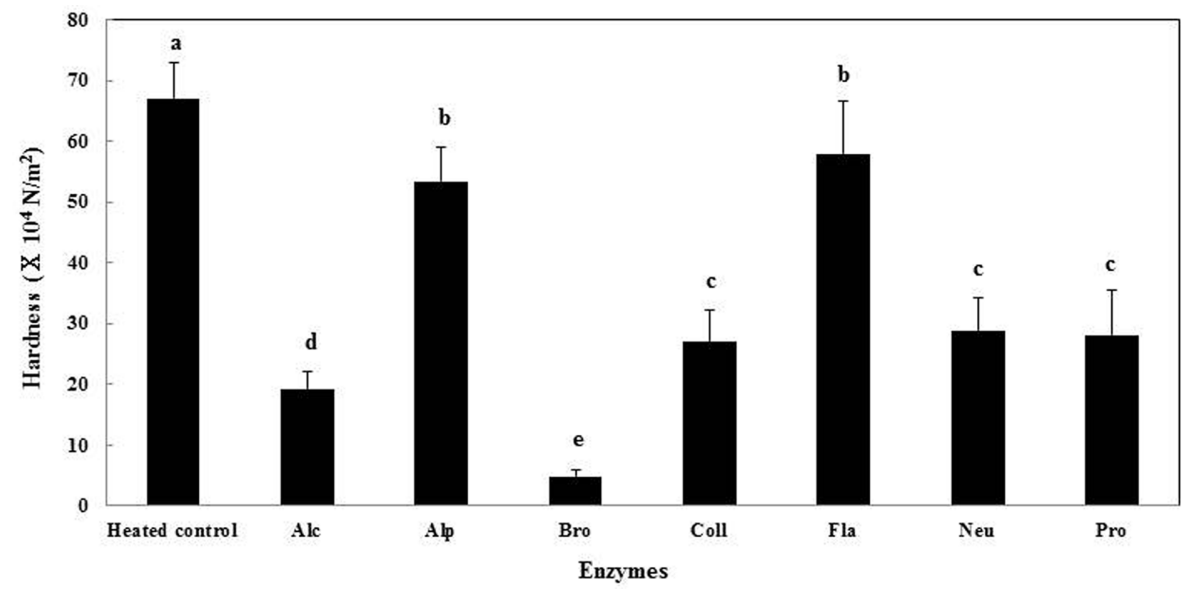

Fig. 3. Hardness of the eye of round beef processed using the enzyme injection method. Reactions were carried out at $4{ }^{\circ} \mathrm{C}$ for $24 \mathrm{~h}$. Different letters indicate statistically significant difference $(p<0.05)$. Alc, alcalase 2.4L FG; Alp, alphalase NP; Bro, bromelain 1200 GDU; Coll, collupulin MG; Fla, flavourzyme 500MG; Neu, neutrase 0.8L; Pro, protamax. 


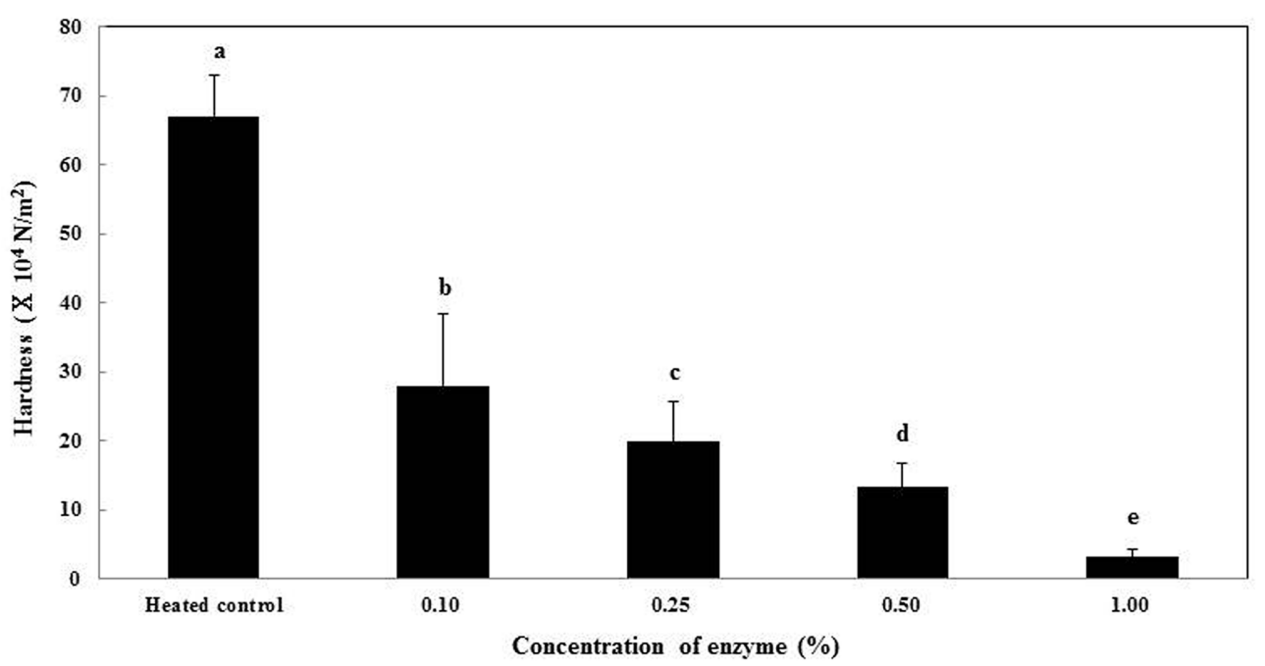

Fig. 4. Effect of bromelain enzyme concentrations on hardness of eye of round beef processed using the enzyme injection method. Enzyme reactions were carried out at $4{ }^{\circ} \mathrm{C}$ for $24 \mathrm{~h}$. Different letters indicate significant difference $(p<0.05)$.

ness of $3.2 \times 10^{4} \mathrm{~N} / \mathrm{m}^{2}$ at an enzyme concentration of $1.00 \%$ (Fig. 4), showing a large degree of softening. The sample shape for the eye of round beef at concentrations of $1.00 \%$ was only retained until anything more than slight stress was applied; the sample shape for the eye of round beef disintegrated. In contrast, the samples were softened to some degree at decreased concentrations of $0.25 \%$ and $0.50 \%$. The hardness of eye of round was $2.8 \times 10^{5} \mathrm{~N} / \mathrm{m}^{2}$ at an enzyme concentration of $0.10 \%, 2.0 \times 10^{5} \mathrm{~N} / \mathrm{m}^{2}$ at $0.25 \%$, and $1.3 \times 10^{4} \mathrm{~N} / \mathrm{m}^{2}$ at $0.50 \%$. Therefore, eye of round beef treated with Bro at $1.00 \%$ can be recognized as fitting the criteria of UDF 2 (that is, it can be broken up by the gums). Eye of round beef treated with Brom can be prepared for individuals who have mastication and swallowing problems. Above all things, it is necessary when cooking to use these enzymes at an optimum concentration.

In conclusion, several methods are used to soften meat, including immersing the meat in a marinade, injecting and tumbling with a marinade, or a combination of injecting and tumbling (Ergezer and Gocke, 2011). Softening is the most important feature in food texture and has the greatest influence on the perception of a given food among the elderly. The findings in this study show that "care food" products for patients admitted to the hospital and elderly patients with mastication or swallowing disorders (a)

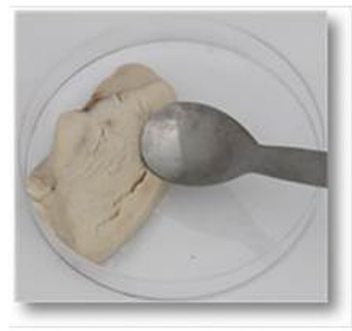

(b)

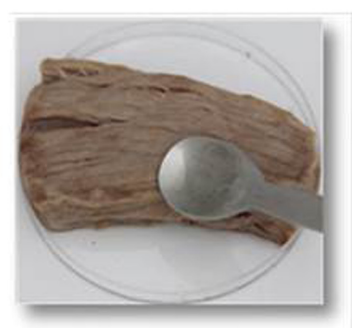

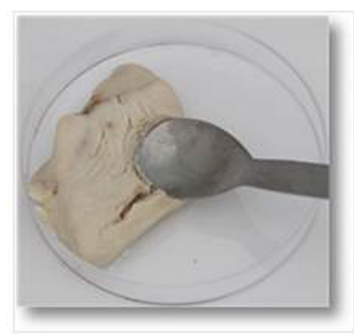

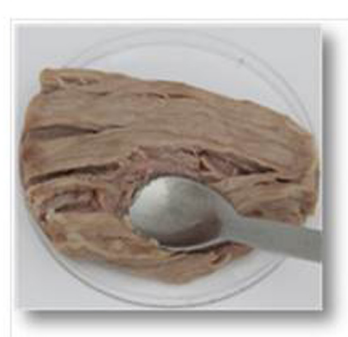

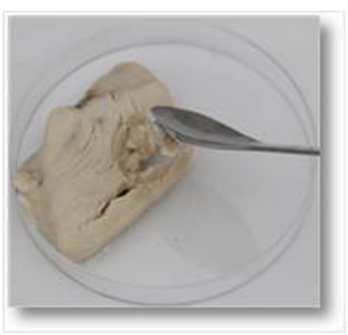

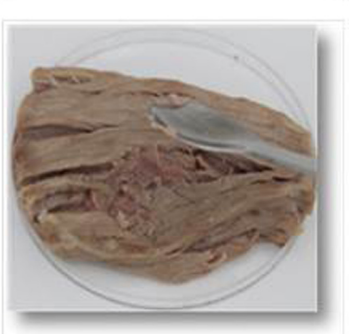

Fig. 5. Appearance of chicken breast (a) and eye of round beef (b) softened by $1 \%$ bromelain injection method with a spoon by hand. 
or disruptions can be obtained by controlling enzyme reaction times and enzyme concentrations with enzyme injections. Although limited information exists concerning the softening of food products for the elderly in Korea, there are a variety of care foods, including frozen foods, retort foods, and dysphagia thickening agents, for people in Japan with reduced ability to masticate according to the UDF concept established by the Japan Care Food Conference (Sasada et al., 2011). The UDF standard has four categories (I to IV) of care foods. The texture of these foods is provided with consideration of masticatory/ swallowing ability and oral sensation in dysphagic patients (Yokoyama et al., 2014).

Moreover, $30 \%$ of people over the age of 65 years are at risk of protein intake below the Recommended Dietary Allowance based on the survey by the Ministry of Health and Welfare of Korea (2011). Therefore, Korea also needs to establish standards to provide Korean care food that adheres to a set of appropriate guidelines. Collectively, chicken breast and eye of round beef treated with an enzyme injection can be easily mashed between the alveolar arches without teeth (Fig. 5(a), 5(b)) and therefore fit UDF category II (Nakatsu et al., 2012). This research revealed that the degree of softening in chicken breast and eye of round beef with the injection of protease enzymes can be altered by selective enzymes Bro and Coll. Further study will be required to provide commercialized Korean care food products in accordance with a new type of enzyme invention for injection and with the classification of processing technologies. We hope the results of the present investigation contribute to the development of Korean care food.

\section{Acknowdgements}

This work was financially supported by the Korea Food Research Institute (E0145101-02).

\section{References}

1. Bartkiene, E., Jakobsone, I., Juodeikiene, G., Vidmantiene, D., Pugajeva, I., and Bartkevics, V. (2013) Study on the reduction of acrylamide in mixed rye bread by fermentation with bacteriocin-like inhibitory substances producing lactic acid bacteria in combination with Aspergillus niger glucoamylase. Food Control 30, 35-40.

2. Calkins, C. R. and Sullivan, G. (2007) Adding enzymes to improve beef tenderness (Beef Facts: Product Enhancement series). National Cattlemen's Beef Association, Colorado, USA.

3. Chizu, T., Sohsuke, T., Daizoh, H., Sei, C., and Kiyoka, I.
(2013) The jelly in jelly of the staple food style. JP Patent 2013-208103.

4. Cupp-Enyard, C. (2008) Sigma's non-specific protease activity assay - Casein as substrate. J. Vis. Exp. 19.

5. Deutz, N. E., Bauer, J. M., Barazzoni, R., Biolo, G., Boirie, Y., Bosy-Westphal, A., Cederholm, T., Cruz-Jentoft, A., Krznariç, Z., Nair, K. S., Singer, P., Teta, D., Tipton, K., and Calder, P. C. (2014) Protein intake and exercise for optimal muscle function with aging: Recommendations from the ESPEN Expert Group. Clin. Nutr. 33, 929-936.

6. Ergezer, H. and Gocke, R. (2011) Comparison of marinating with two different types of marinade on some quality and sensory characteristics of turkey breast meat. J. Anim. Vet. Adv. 10, 60-67.

7. Evaluation of Food Texture. Shimadzu Corp. Application Data Sheet No. 12. Assessed 30 Feb, 2015, Available from: https:// shimadzu.com.au/sites/default/files/LAAN-J-AG-E012.pdf

8. Goto, R., Takei, R., Kitamura, K., Sugimura, K. I., and Kuribayashi, M. (2008) Food product suitable for person who has difficulty in chewing or swallowing. US Patent 12/681,233.

9. Harris, S. E., Huff-Lonergan, E., Lonergan, S. M., Jones, W. R., and Rankins, D. (2001) Antioxidant status affects color stability and tenderness of calcium chloride-injected beef. $J$. Anim. Sci. 79, 666-677.

10. Hoffman, J. R. and Falvo, M. J. (2004) Protein-which is best? J. Sports Sci. Med. 3, 118-130.

11. Japan Care Food Conference. Available from: http://www. udf.jp/about/table.html (Japanese).

12. Keen, C. L. and Zidenberg-Cherr, S. (1994) Should vitaminmineral supplements be recommended for all women with childbearing potential? Am. J. Clin. Nutr. 59, 532S-538S.

13. Kim, S. (2000). The challenge of rapid ageing and low fertility in Korea. Beyond Flexibility Roadmaps for Korean Labor Policy 2018, 35.

14. Kwon, Y. S., Kim, Y., Lee, J. Y., Choe, J. S., Kim, H. R., and Kim, Y. (2013) An exploratory study of foods served to guests of head families (Jong-ga). J. Korean Soc. Food Cult. 28, 1230.

15. Liu, C., Xiong, Y. L., and Rentfrow, G. K. (2011) Kiwifruit protease extract injection reduces toughness of pork loin muscle induced by freeze-thaw abuse. LWT-Food Sci. Technol. 44, 2026-2031.

16. Ministry of Health and Welfare of Korea, Korea Centers for Disease Control and Prevention. 2011 Korea Health Statistics. Seoul: Ministry of Health and Welfare of Korea; 2012 [in Korean].

17. Nakatsu, S., Kohyama, K., Watanabe, Y., Shibata, K., Sakamoto, K., and Shimoda, M. (2012) Mechanical properties of softened foodstuffs processed by freeze-thaw infusion of macerating enzyme. Innov. Food Sci. Emerg. 16, 267-276.

18. Palmer, J. B., Drennan, J. C., and Baba, M. (2000) Evaluation and treatment of swallowing impairments. Am. Fam. Physician 61, 2453-2462.

19. Rothenberg, E., Ekman, S., Bülow, M., Möller, K., Svantesson, J., and Wendin, K. (2007) Texture-modified meat and carrot products for elderly people with dysphagia: Preference 
in relation to health and oral status. Scand. J. Food Nutr. 51, 141-147.

20. Sakamoto, K., Shibata, K., and Ishihara, M. (2006) Decreased hardness of dietary fiber-rich foods by the enzyme-infusion method. Biosci. Biotechnol. Biochem. 70, 1564-1570.

21. Sasada, Y., Sasada, Y., Nakadate, A., Kudou, R., Shigeta, K., Suzuno, H., Ishida, H., Suzuki, K., and Kashimura, O. (2008) Assessment of the physical function of a diet designed for residents at a special elderly nursing home who have difficulties masticating and swallowing. J. Integrated Study Dietary Habits 19, 251-259.

22. Takei, R., Hayashi, M., Umene, S., Narita, K., Kobayashi, Y., and Masunaga, H. (2015) Changes in physical properties of enzyme-treated beef before and after mastication. J. Texture Stud. 46, 3-11.

23. van der Bilt, A. (2002) Human oral function: A review. Braz. J. Oral. Sci. 1, 7-18.

24. Williams, P. (2007) Nutritional composition of red meat. Nutr. Diet. 64, S113-S119.

25. Wolfe, R. R., Miller, S. L., and Miller, K. B. (2008). Optimal protein intake in the elderly. Clin. Nutr. 27, 675-684.

26. Yokoyama, S., Hori, K., Tamine, K. I., Fujiwara, S., Inoue, M., Maeda, Y., Funami, T., Ishihara S., and Ono, T. (2014) Tongue pressure modulation for initial gel consistency in a different oral strategy. PloS one 9, e91920. 